\title{
IMPACT OF ALBANIAN AGRICULTURAL REFORMS \\ IN GJIROKASTRA REGION
}

DOI: http://dx.doi.org/10.18509/GBP.2015.43

UDC: 338.43.021.8(496.572)

\author{
Ass. Prof. Dr.Albina Sinani \\ “Eqrem Çabej” University, Department of Geography, Gjirokastër, Albania
}

\begin{abstract}
The land is the principal tool of production and the solving of property conflicts in municipalities and communes of the region is the first phase of modernizing process in agricultural process. Completing of land registration process will increase efficiency of the abandoned land or the land that is not used in all its area. This will guarantee the farmers of the region to increase the economic activity, the incomes of their families, living standards and the security and guarantee the right of their properties nowadays and in the future. The delivering of the land relatively equally to the villager's families in 1990, resulted with a fragmentation of properties in Gjirokastra Region. Sections of land are very small and often very far from rural dwelling places. Some land parcels are of a very low quality for agricultural purposes and other land are abandoned from the families which have emigrated outside Albanian boarders. Consolidation process of small parcels in agricultural productive plains is happening very slowly. Encouragement and stimulation of parceling is necessary, because the average size of them is $1.26 \mathrm{ha} /$ family in Gjirokastra Region (district of Gjirokastër 1.45, district of Permet 1.43 and district of Tepelenë 0.99 ha/family). This fact shows that the area for the expanding of agricultural operations is small and problems of completing the land registration to take final and proper decisions about its delivering are several ones. Low number of land ownership certificates has been an obstacle for renting of the land and as result increasing of economic activity in order to generate the incomes.
\end{abstract}

KEYWORDS: land market, land registration, consolidation of land parcels, average dimension of land parcels, expending of agricultural operations.

\section{PROGRESS OF THE RADICAL REFORM AND LAND ADMINISTRATION AFTER 1990}

The land is the principal element of agricultural production. After 1990, the land reform has been one of the most concerning problems of agricultural policies, since it slots political, economical institutional and social factors.

Before 1990, there were two cadastral documents:

- Books of the Land with changes of the plots,

- Cadastral maps.

The cadastral stock resulted from the process of land mapping done in the period 19501990. Changes in this stock were approved by Ministry of Agriculture and were registered in the cadastral changing sheets of the plots. When the political system changed, it brought diffraction of farms and cooperatives and also their privatization. Property rapports changed entirely, and it became necessary to have a legal base about ownership. The cadastral system was not able to reflect the changes of the properties in the map, so the state created mortgage system of the Registration of Real Estate. 
In the framework, of legislative reforms about agriculture land that started to depict after 1900, and were approved laws and decisions as following:

•Law nr. 7501 date 19.07.1991"14 "About Land".

-Law nr. 7512 date 10.08.1991, "To authorize and protect private property and free initiatives".

-Decision of Council of Ministers, Nr. 266, date. 08.08.1991, "To divide the properties of former agricultural cooperatives".

-Law nr. 7652 date 23.12.1992, "To privatize state houses".

-Decision of Council of Ministers, Nr. 452, date. 17.10.1992, "To restructure agricultural enterprises".

- Law 7745, date 26.07.1993, "About re-evaluation and delivering in value of former agricultural cooperatives".

-Law 7698, date 15.04.1993, "About returning and compensation of properties of former owners".

-Law 7699, date 21.04.1993 "About compensation in value or land of former owners of agricultural lands, forests and pasture", where the expropriated land will be compensate in monetary value and obligations according to the classes of biological value of the land and the size of expropriated land.

-Law 7715, date. 02.06.1993, "About leasing of the land which is property owned by individuals", with the change of article 3 of law 7501.

-Law 8053, date. 21.12.1995, "About gaining of the agricultural land ownership without any reward" to the farmers that have used it before.

-Law 7836, date. 22.06.1994, "To define the price of the agricultural land in order to compensate the former expropriated owners".

-Law 7843, date. 13.07.1994, “About registration of real estate”, which institutionalised land registering in the new system of assets registering.

In 1994 was created the immensely first legal technique unit named, "Project Management Unit" about the Registration System of Real Estate. Gjirokastra region consists in three registration areas (one for each district) where functioning three registration offices for real estate registration are. Registration areas are divided in cadastral areas according to respective dwelling places. Information of this system created economy bases for the land market, which is a tremendous achievement in the process of ownership reforms on land. In Gjirokastra region were created 209.021, real estate (from 5 million in the whole country), from which 194.076 were rural ones.

Table 1. Registringof real estate Gjirokastra region

\begin{tabular}{|l|c|c|c|c|c|}
\hline \multirow{2}{*}{ Description } & \multicolumn{5}{|c|}{ Cadastral area } \\
\cline { 2 - 6 } & Total & Urban & Rural & $\begin{array}{c}\text { In the } \\
\text { process }\end{array}$ & $\begin{array}{c}\text { Not in the } \\
\text { process }\end{array}$ \\
\hline Region & 277 & 8 & 269 & 204 & 73 \\
\hline Gjirokastër & 98 & 4 & 94 & 87 & 11 \\
\hline Përmet & 100 & 2 & 98 & 46 & 54 \\
\hline Tepelenë & 79 & 2 & 77 & 71 & 8 \\
\hline
\end{tabular}

\begin{tabular}{|l|c|c|c|c|}
\hline \multirow{2}{*}{ Description } & \multicolumn{2}{|c|}{ Number of assets } & \multirow{2}{*}{$\begin{array}{c}\text { Total registered } \\
\text { surface (in ha) }\end{array}$} \\
\cline { 2 - 3 } & Total & Urban & Rural & \\
sure
\end{tabular}

\footnotetext{
${ }^{14}$ Vata. N. "Registration of land, the integration of its indicators". GEER. Tiranë 2005.
} 


\begin{tabular}{|l|c|c|c|c|}
\hline Region & 209021 & 14945 & 194076 & 130245.4713 \\
\hline Gjirokastër & 105672 & 3256 & 102416 & 59550.81205 \\
\hline Përmet & 47176 & 2289 & 44887 & 21113.57216 \\
\hline Tepelenë & 56173 & 9400 & 46773 & 49581.08705 \\
\hline
\end{tabular}

In Gjirokastër region, there are 73 areas that are not part of the registration system:

- 11 in Gjirokastra district,

- 54 in Përmet district,

- 8 in Tepelena district.

Implementation of "Law of Land" passed through two phases.

\section{First phase (April-July 1991)}

With Decision of Council of Ministers nr.151, date 26.04.1991, was delivered land to the village families and former employees of cooperatives and agricultural enterprises, despite they were living in the village or in towns. This phase did not touch the ownership on land even cooperatives and agricultural enterprises.

Table 2. Land stock and indicators of land delivery

\begin{tabular}{|c|c|c|c|c|c|c|c|c|}
\hline \multirow{2}{*}{ Land } & \multirow{2}{*}{ Total } & \multirow{2}{*}{$\begin{array}{c}\text { Agricult } \\
\text { ural }\end{array}$} & \multirow{2}{*}{$\begin{array}{c}\text { Mead } \\
\text { ow }\end{array}$} & \multicolumn{2}{|c|}{ Pastures } & \multirow{2}{*}{ Forest } & \multirow{2}{*}{$\begin{array}{c}\text { Terrai } \\
\text { n }\end{array}$} & \multirow{2}{*}{$\begin{array}{c}\text { Not } \\
\text { agricultural }\end{array}$} \\
\hline & & & & Natural & Cultivated & & & \\
\hline Region & 288432 & 45201.5 & 146 & 97754 & 1090 & 86061 & 1571.5 & 56608 \\
\hline Gjirokastër & 113740 & 17667 & 146 & 45256 & 235 & 30471 & 908 & 19057 \\
\hline Përmet & 92958 & 14479.5 & - & 22861 & 480 & 38340 & 376.5 & 16421 \\
\hline Tepelenë & 81734 & 13055 & - & 29637 & 375 & 17250 & 287 & 21130 \\
\hline \multicolumn{9}{|c|}{ 1. Former state sector } \\
\hline Region & 14324 & 5996 & 144 & 5666 & 45 & 1327 & 185 & 961 \\
\hline Gjirokastër & 13003 & 4675 & 144 & 5666 & 45 & 1327 & 185 & 961 \\
\hline Përmet & 1147 & 1147 & - & - & - & - & - & - \\
\hline Tepelenë & 174 & 174 & - & - & - & - & - & - \\
\hline \multicolumn{9}{|c|}{ 2. Former cooperatives' sector } \\
\hline Region & 56893.5 & 39205.5 & 2 & 11888 & 190 & 1826 & 795 & 2987 \\
\hline Gjirokastër & 30433 & 12992 & 2 & 11888 & 190 & 1826 & 548 & 2987 \\
\hline Përmet & 13579.5 & 13332.5 & - & - & - & - & 247 & - \\
\hline Tepelenë & 12881 & 12881 & - & - & - & - & - & - \\
\hline
\end{tabular}

\begin{tabular}{|c|c|c|c|c|c|c|}
\hline \multicolumn{7}{|c|}{ 3. Other public lands } \\
\hline \multirow[b]{2}{*}{ Land } & \multirow{2}{*}{ Total } & \multicolumn{2}{|c|}{ Pastures } & \multirow{2}{*}{ Forest } & \multirow{2}{*}{ Terrain } & \multirow{2}{*}{$\begin{array}{c}\text { Not } \\
\text { agricultural }\end{array}$} \\
\hline & & Natural & Cultivated & & & \\
\hline Region & 217214.5 & 80200 & 855 & 82908 & 591.5 & 52660 \\
\hline Gjirokastër & 70304 & 27702 & - & 27318 & 175 & 15109 \\
\hline Përmet & 78231.5 & 22861 & 480 & 38340 & 129.5 & 16421 \\
\hline Tepelenë & 68679 & 29637 & 375 & 17250 & 287 & 21130 \\
\hline
\end{tabular}

Source: According to cadastre in the Gjirokastra region (in ha)

- The tasks of the first phase were:

Completing of registration and updating of data about land.

Defining the final destination about undelivered land.

Increased soil fertility.

Improving the watering and drainage systems.

Use of modern technologies to increase producing capacities of land.

Preserving the land from the process of erosion. 
Figure 1. Land stock and indicators of land delivery (agricultural land, meadow, former state sector, natural and cultivated pastures)

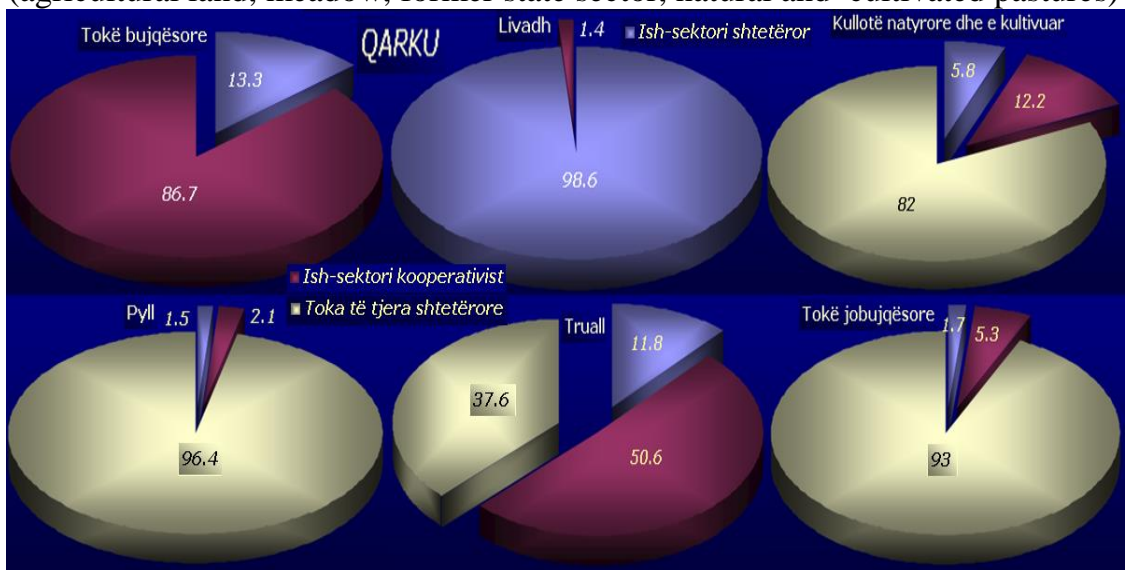

According to cadastre, $61.8 \%$ of lands in Gjirokastra district were part of other public land stocks, $26.8 \%$ lands of former cooperative sector and $11.4 \%$ lands of former state sector; meanwhile land of Përmet and Tepelenë districts were part of other public land stocks.

\section{Second phase}

In 19.07.1991 parliament approved the Law $\mathrm{nr} 7501$, which has in its principles transferring the ownership of agricultural economy, from public property to private ones. This law opened the way for implementation in practice of all ownership changes in agriculture, transforming so the cooperatives and agricultural enterprises, supporting the right of ownership on the land. Certainly re ownership of agricultural land, inventory of agricultural mechanicals and livestock, in the former cooperatives of socialist type, was a real difficult, process.

Table 3. Families of former cooperatives and agricultural enterprises and number of farmers

\begin{tabular}{|l|c|c|c|c|}
\hline \multicolumn{1}{|c|}{ Former families of- } & \multicolumn{2}{c|}{$\begin{array}{c}\text { Agricultural } \\
\text { cooperatives. }\end{array}$} & \multicolumn{2}{c|}{$\begin{array}{c}\text { Agricultural } \\
\text { enterprises. }\end{array}$} \\
\hline \multicolumn{1}{|c|}{ Year } & $\mathbf{1 9 9 4}$ & $\mathbf{1 9 9 9}$ & $\mathbf{1 9 9 4}$ & $\mathbf{1 9 9 9}$ \\
\hline Gjirokastër District & 7356 & 7309 & 2407 & 2698 \\
\hline Përmet District & - & 5869 & - & 404 \\
\hline Tepelenë District & 7184 & 7058 & 600 & 215 \\
\hline
\end{tabular}

\begin{tabular}{|l|c|c|c|}
\hline Number of farmers & $\mathbf{1 9 9 4}$ & $\mathbf{1 9 9 9}$ & $\mathbf{2 0 0 4}$ \\
\hline Gjirokastër Region & 24866 & 23782 & 23510 \\
\hline Urban space & 1829 & 1601 & 1966 \\
\hline Rural space & 23037 & 22181 & 21544 \\
\hline Gjirokastër District & 10385 & 10027 & 10576 \\
\hline Përmet District & 6697 & 6697 & 6994 \\
\hline Tepelenë District & 7784 & 7058 & 5940 \\
\hline
\end{tabular}

This law was implemented to all agricultural lands and in 30.09.1991 were diffracted agricultural cooperatives, agricultural structure changed, the land was privatised, and it was owned by former employees and members of agricultural cooperatives being delivered on bases of the number of members had each family. Villagers were equipped with Act of the land ownership (land patent). Being equipped with ownership documents it was created a positive clime to increase the care for the agricultural land. 
Table 4. Land stock in Gjirokastra Region in 01.08.1991, (in ha)

\begin{tabular}{|l|c|c|c|c|c|}
\hline \multicolumn{2}{|c|}{ In Total } & Agricultural land & Orchards & Vineyards & Olives \\
\hline Region & 45201.5 & 37610.8 & 5487.4 & 1396.7 & 706.6 \\
\hline Gjirokastër & 17667 & 14823 & 2070 & 684 & 90 \\
\hline Përmet & 14479.5 & 11905.8 & 2059.4 & 472.7 & 41.6 \\
\hline Tepelenë & 13055 & 10882 & 1358 & 240 & 575 \\
\hline \multicolumn{5}{|c|}{ a. Former cooperative sector } \\
\hline Region & 39205.5 & 33191.2 & 4317 & 1072 & 625.6 \\
\hline Gjirokastër & 12992 & 11152 & 1209 & 557 & 74 \\
\hline Përmet & 13332.5 & 11244.2 & 1798 & 281.7 & 8.6 \\
\hline Tepelenë & 12881 & 10795 & 1310 & 233 & 543 \\
\hline \multicolumn{7}{|c|}{ b. Former agricultural enterprises } \\
\hline Region & 5996 & 4419.6 & 1170.4 & 325 & 81 \\
\hline Gjirokastër & 4675 & 3671 & 861 & 127 & 16 \\
\hline Përmet & 1147 & 661.6 & 261.4 & 191 & 33 \\
\hline Tepelenë & 174 & 87 & 48 & 7 & 32 \\
\hline
\end{tabular}

Based on Decision of Council of Ministers nr 452, date 17.10.1992, "About reconstruction of agricultural enterprises" 15 :

- Agricultural enterprises created mainly from the delivery process of the former cooperatives land to the families of agricultural enterprises.

- The gained land from irrigation, deforestation and nationalization of agricultural enterprises remained state properties and leased to the family members of former agricultural enterprises, for an indefinite period in the contract.

Features of land reform

- It was quick and radical and during its implementation government didn't take in consideration the ownership of the land before 1945.

- Diffraction process of cooperatives and agricultural enterprises was accompanied with uncontrollable damages and embezzlements that brought serious damages of watering and drainage system, animals, orchards etc.

- Created a big segmentation of the land surface in small farms.

Law Nr. 7501, in Gjirokastra region was implemented in 267 villages (94 villages of Gjirokastra district, 96 of Përmet district and 77 of Tepelenë district). In 1994 from the stock of agricultural land was delivered from 30.120 ha, meanwhile in 1999 were delivered 30.375 ha land, and were given 8.114 land patents in Gjirokastra district and 6.012 land patents in Tepelenë district. A total of 17.663 ha agricultural land given from the cadastral office for Gjirokastra district, were delivered according to the law accompanied with the respective land patents for 14.786 ha land (10.693 ha from former cooperative sector and 4093 ha from former state sector). In 1999 in Gjirokastra district remained undelivered 2.877 ha land $(2.297$ ha from former cooperative sector and 580 ha from state sector), meanwhile in Tepelenë district 6.322 ha agricultural land. After the approval of Law 8312 date 26.03.1998 and Decision of Council of Ministers Nr.531 date.21.08.1998, "About undelivered agricultural land", the surface of delivered land through the implementation of them reached up to 945 ha or $6.6 \%$ of undelivered surface, 700 ha for Gjirokastra district, 95 ha for Përmet district and 150 ha for Tepelenë district. In 2004 were delivered $67.3 \%$ of the stock of agricultural land.

The reasons of delivering the undelivered land with such low percentage were:

\footnotetext{
15 Official Bulletin 1992, Tiranë 1995.
} 
- Demographic movements decreased the interest about land.

- Insufficient work and malfunctioning of commissions in communes and villages.

- Use of agricultural land with agricultural plants in a mass of $70 \%$, meanwhile $30 \%$ is not fertilised and it is used as pasture for the livestock, smoothing the high deficit of pastures for the livestock.

About the completing of land reforms and conflict solving served as obstacles many factors:

-Administrative irresponsible actions.

- Not updating of documentations.

- Occupations of lands from former owners, despite the legal dispositions.

Table 5. Land privatization given from cadastral office (in ha)

\begin{tabular}{|l|c|c|c|c|c|c|}
\hline Description & \multicolumn{2}{|c|}{ Agricultural land in total : } & \multicolumn{3}{c|}{ 1. delivered: } \\
\hline \multicolumn{1}{|c|}{ years } & $\mathbf{1 9 9 4}$ & $\mathbf{1 9 9 9}$ & $\mathbf{2 0 0 4}$ & $\mathbf{1 9 9 4}$ & $\mathbf{1 9 9 9}$ & $\mathbf{2 0 0 4}$ \\
\hline Region & 44474 & 45244 & 45201.5 & 30120 & 30853 & 30437 \\
\hline Urban space & 1016 & 2854 & 2433 & 584 & 1818 & 1796 \\
\hline Rural space & 43458 & 42390 & 42768.5 & 29536 & 29035 & 28641 \\
\hline Gjirokastër & 16739 & 17663 & 17667 & 13495 & 14786 & 14932 \\
\hline Përmet & 14680 & 14526 & 14479.5 & 9417 & 9334 & 9213 \\
\hline Tepelenë & 13055 & 13055 & 13055 & 7208 & 6733 & 6292 \\
\hline
\end{tabular}

\begin{tabular}{|l|c|c|c|c|c|c|}
\hline Description & \multicolumn{3}{|c|}{ a. agricultural land } & \multicolumn{3}{c|}{ b. orchards: } \\
\hline \multicolumn{1}{|c|}{ years } & $\mathbf{1 9 9 4}$ & $\mathbf{1 9 9 9}$ & $\mathbf{2 0 0 4}$ & $\mathbf{1 9 9 4}$ & $\mathbf{1 9 9 9}$ & $\mathbf{2 0 0 4}$ \\
\hline Region & 28193.1 & 28837.6 & 27360.15 & 1926.9 & 2015.4 & 3076.85 \\
\hline Urban space & 557 & 1693 & 1512.5 & 27 & 125 & 283.5 \\
\hline Rural space & 27636.1 & 27144.6 & 25847.65 & 1899.9 & 1890.4 & 2793.35 \\
\hline Gjirokastër & 12654.6 & 13945.6 & 14635.45 & 840.4 & 840.4 & 296.55 \\
\hline Përmet & 8756 & 8411 & 6817 & 661 & 923 & 2396 \\
\hline Tepelenë & 6782.5 & 6481 & 5907.7 & 425.5 & 252 & 384.3 \\
\hline
\end{tabular}

\begin{tabular}{|l|c|c|c|c|c|c|}
\hline Description & \multicolumn{3}{|c|}{$\mathbf{b}^{\mathbf{1}}$ Orchards } & \multicolumn{3}{c|}{$\mathbf{b}^{2}$. Vineyards } \\
\hline \multicolumn{1}{|c|}{ Years } & $\mathbf{1 9 9 4}$ & $\mathbf{1 9 9 9}$ & $\mathbf{2 0 0 4}$ & $\mathbf{1 9 9 4}$ & $\mathbf{1 9 9 9}$ & $\mathbf{2 0 0 4}$ \\
\hline Region & 1154 & 1233 & 1996.7 & 457.4 & 502.4 & 792.35 \\
\hline Urban space & 27 & 48 & 192 & & 37 & 41.4 \\
\hline Rural space & 1127 & 1185 & 1804.7 & 457.4 & 465.4 & 750.95 \\
\hline Gjirokastër & 494 & 494 & 8.7 & 272.4 & 272.4 & 279.85 \\
\hline Përmet & 477 & 669 & 1931 & 172 & 222 & 424 \\
\hline Tepelenë & 183 & 70 & 57 & 13 & 8 & 88.5 \\
\hline
\end{tabular}

\begin{tabular}{|l|c|c|c|c|c|c|}
\hline Description & \multicolumn{3}{|c|}{$\mathbf{b}^{\mathbf{3}}$. Olives } & \multicolumn{3}{c|}{ 2. undelivered } \\
\hline \multicolumn{1}{|c|}{ Years } & $\mathbf{1 9 9 4}$ & $\mathbf{1 9 9 9}$ & $\mathbf{2 0 0 4}$ & $\mathbf{1 9 9 4}$ & $\mathbf{1 9 9 9}$ & $\mathbf{2 0 0 4}$ \\
\hline Region & 315.5 & 280 & 287.8 & 14381 & 14391 & 14764.5 \\
\hline Urban space & & 40 & 50.1 & 459 & 1036 & 637 \\
\hline Rural space & 315.5 & 240 & 237.7 & 13922 & 13355 & 14127.5 \\
\hline Gjirokastër & 74 & 74 & 8 & 3244 & 2877 & 2735 \\
\hline Përmet & 12 & 32 & 41 & 5263 & 5192 & 5266.5 \\
\hline Tepelenë & 229.5 & 174 & 238.8 & 5847 & 6322 & 6763 \\
\hline
\end{tabular}

Analyze of privatization process in the space aspect is showing the existent problems that have Tepelena District, where there are undelivered $51.8 \%$ of the stock of agricultural 
land, the situation is better for the Permet district with round $36.4 \%$ Gjirokastra district, that have only $15.5 \%$ of the stock undelivered.

Table 6. Land privatization given from cadastral office (in ha)

\begin{tabular}{|l|c|c|c|c|}
\hline \multirow{2}{*}{ Land } & \multirow{2}{*}{ Total : } & \multirow{2}{*}{ delivered } & \multicolumn{2}{c|}{ Former sector } \\
\cline { 4 - 5 } & & & cooperative & state \\
\hline Region & 45201.5 & 31525 & 26741 & 4784 \\
\hline Gjirokastër & 17667 & 14932 & 10926 & 4006 \\
\hline Përmet & 14479.5 & 9221 & 8517 & 704 \\
\hline Tepelenë & 13055 & 7372 & 7298 & 74 \\
\hline
\end{tabular}

\begin{tabular}{|l|c|c|c|c|c|c|}
\hline \multirow{2}{*}{ Land } & \multirow{2}{*}{ undelivered : } & \multirow{2}{*}{$\begin{array}{c}\text { Former } \\
\text { cooperative } \\
\text { sector : }\end{array}$} & \multicolumn{2}{|c|}{ refused evaluable terrains ) } & \multirow{2}{*}{$\begin{array}{c}\text { Former } \\
\text { for: }\end{array}$} \\
\cline { 4 - 6 } & & & $\begin{array}{c}\text { being } \\
\text { far }\end{array}$ & $\begin{array}{c}\text { being } \\
\text { far }\end{array}$ & $\begin{array}{c}\text { Low } \\
\text { fertility }\end{array}$ & sector \\
\hline Region & 13676.5 & 12762 & 1946 & 1526 & 9290 & 914.5 \\
\hline Gjirokastër & 2735 & 2288 & 500 & - & 1788 & 447 \\
\hline Përmet & 5258.5 & 4826 & 1200 & 1526 & 2100 & 432.5 \\
\hline Tepelenë & 5683 & 5648 & 246 & - & 5402 & 35 \\
\hline
\end{tabular}

Figure 2. Land privatization (in ha)

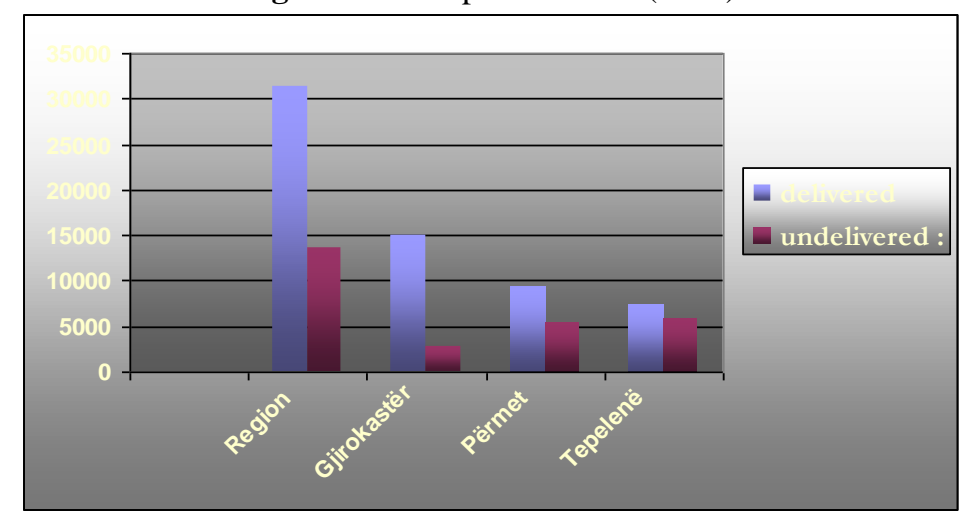


Map 1. Map of agricultural land privatization (land delivered with red colour and land undelivered with green colour)

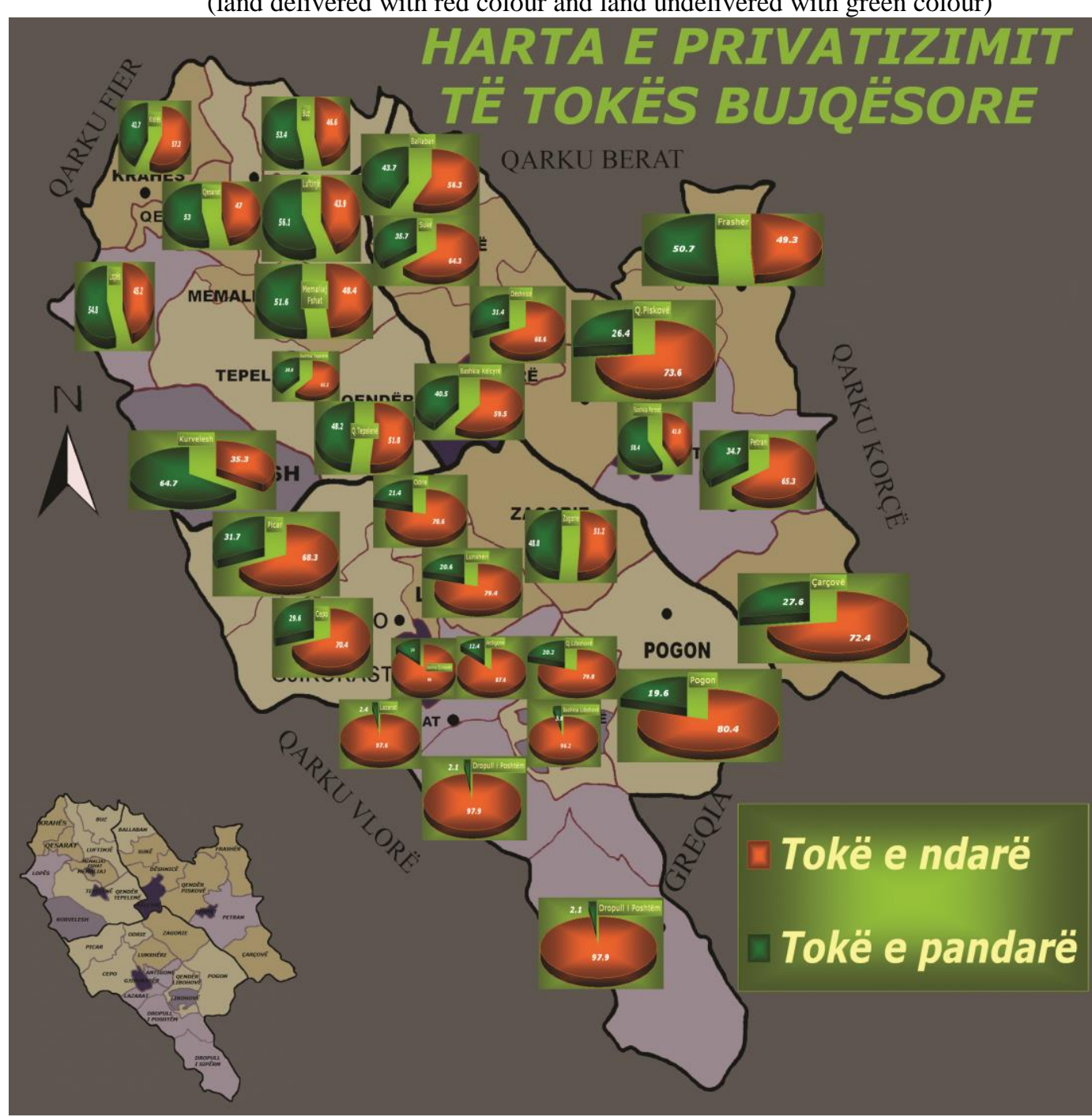

Table 7. Surface for each member of family in the Gjirokastër region

\begin{tabular}{|c|c|c|c|c|c|}
\hline Benefit land & Total number & \multicolumn{2}{|c|}{ From the former sector } & Ha/member & \multirow{2}{*}{ Ha/family } \\
\cline { 3 - 6 } Have a land patent & of families & of cooperatives & of state & of family & \\
\hline Gjirokastër Region & 23828 & 20441 & 3387 & 0.28 & 1.26 \\
\hline Gjirokastër district & 10170 & 7640 & 2530 & 0.32 & 1.3 \\
\hline Përmet district & 6372 & 5605 & 767 & 0.34 & 1.45 \\
\hline Tepelenë district & 7286 & 7196 & 90 & 0.19 & 0.94 \\
\hline
\end{tabular}

\begin{tabular}{|c|c|c|c|c|c|}
\hline \multirow{2}{*}{$\begin{array}{l}\text { Gjirokastër district } \\
\text { Communes }\end{array}$} & \multirow{2}{*}{$\begin{array}{ll}0.326 \\
0.326 \\
\end{array}$} & \multirow{2}{*}{\multicolumn{2}{|c|}{ Ha/family member }} & \multirow{2}{*}{$\begin{array}{l}\text { Tepelenë district } \\
\text { Municipalities }\end{array}$} & \multirow{2}{*}{$\begin{array}{l}0.19 \\
0.04\end{array}$} \\
\hline & & & & & \\
\hline Antigone & 0.43 & Përmet district & 0.34 & Tepelenë & 0.05 \\
\hline Cepo & 0.22 & Municipalities & 0.35 & Memaliaj & 0.03 \\
\hline Dropull i Poshtëm & 0.422 & Këlcyrë & 0.35 & Communes & 0.21 \\
\hline Dropull i Sipërm & 0.304 & Communes & 0.34 & Buz & 0.28 \\
\hline Lazarat & 0.206 & Ballaban & 0.29 & Krahës & 0.22 \\
\hline Lunxhëri & 0.39 & Çarçovë & 0.36 & Kurvelesh & 0.1 \\
\hline Odrie & 0.39 & Dëshnicë & 0.35 & Lopës & 0.24 \\
\hline Picar & 0.22 & Frashër & 0.3 & Luftinjë & 0.17 \\
\hline
\end{tabular}




\begin{tabular}{|l|c|l|c|l|c|}
\hline Pogon & 0.345 & Petran & 0.41 & Memaliaj Fshat & 0.25 \\
\hline Qendër Libohovë & 0.35 & Qendër Piskovë & 0.41 & Qendër Tepelenë & 0.18 \\
\hline Zagorie & 0.384 & Sukë & 0.27 & Qesarat & 0.24 \\
\hline
\end{tabular}

The smallest surface of the agricultural land for each person it belongs to Tepelena district, meanwhile the biggest surface it belongs to Permet district.

Consequences of agricultural reform:

-Were substituted big units of agricultural products with small familiar units that possessed averagely $1.26 \mathrm{ha}$ /family ( $1.17 \mathrm{ha}$ /family in the whole country), divided in 3 4 plots;

-Process was accompanied with a chaotic urbanization, big segmentation and misuse of agricultural lands;

-Agricultural infrastructure, watering and draining system and trading of agricultural products was very damaged;

- Law Nr. 7501 didn't take in consideration the ownership of the land before the Agricultural Reform in1945-1946;

-Agricultural land wasn't returned to the former owners of before collectivization phase; - Agricultural land was delivered to the families that were living in the village till 31 July 1991;

-Employment level in rural areas was increased;

-Were created premises for interior migrations (toward flat areas and urban centres creating informal inhabitation areas) and emigration of rural population outside the country (mainly in Greece and Italy);

- Remittances of money from outside favour laziness and parasitism of rural population, abandoning the land decreasing the agricultural production.

In such conditions it was necessary:

- To complete land registration;

- To complete re ownership of former owners, that will bring revitalization of agricultural economy and increase of investments;

- Good administration of agricultural land;

- Rehabilitation of watering and draining system, especially of irrigation channels of second and third hand owned by the farmers, since the damage of damns and embankments caused over flooding of agricultural areas in communes of Luftinjë, Krahës, Buz, Qesarat, Sukë, Dëshnicë, Ballaban etj;

- Rehabilitation of watering and draining system, since the damage of damns and embankments caused over flooding of agricultural areas in communes of Luftinjë, Krahës, Buz, Qesarat, Sukë, Dëshnicë, Ballaban etj;

- It is created a private sector of seeds production, agricultural mechanicals, inputs and agro chemicals;

- To protect the land from erosions and to increase it fertility;

- To do re dimensioning of plots to make them rentable and suitable for the application of modern technologies;

- To improve lands through planting of improved products (crops, fodders grown in hilly areas (5-25\%) and mountainous areas (over 25\%);

- Improving production of plants livestock, agro food products and fishing;

- To protect agricultural land from illegal constructions, which were decreasing its stock;

- To create and develop functional market of the land; 
- Organizing of financial service system in rural areas;

- To solve furnishing with inputs and transferring of technologies;

- Reorganizing and modernizing markets, local and regional agricultural markets;

- To improve and modernise information and technical assistance in agriculture.

\section{STRUCTURAL CHANGES IN AGRICULTURAL SECTOR AND ITS PERSPECTIVE}

Since after the first year, of privatization there were important changes in the planting structure. Industrial plants were not planted anymore since there was no more industry to process them. During the period 1992-1996 there was an increase of agricultural products, but the collapse of pyramidal schemes put the country in a crisis.

The situation it became worse when it was destabilised in September 1998, the War in Kosovo, and the refugees flux in 1999 so despite the growth of agricultural production, was not able to reach the indicators of 1989. After 1990 was reduced the use of chemicals, watered and drained surface, level of mechanicals (Mechanical agricultural enterprises were privatised and most of their machineries emerged out of use). Most of the agricultural production has a destination for personal use; meanwhile the market was furnished with corns and other important products that have been imported. High prices of agricultural products imported from other countries, increased the life cost for the inhabitants of rural and urban areas.

Table 8. Dynamic, value and structure of general agricultural production incomes

\begin{tabular}{|c|l|l|l|l|l|l|l|l|}
\hline \multicolumn{3}{|c|}{$\begin{array}{c}\text { Dynamic of agricultural products } \\
\text { according to the branches in \%. }\end{array}$} & \multicolumn{3}{c|}{$\begin{array}{c}\text { Value of agricultural production } \\
\text { in million leke. }\end{array}$} \\
\hline Vitet & Total & $\begin{array}{l}\text { Agricultural } \\
\text { plants }\end{array}$ & $\begin{array}{l}\text { Live } \\
\text { stock }\end{array}$ & Orchards & Total & $\begin{array}{l}\text { Agricultural } \\
\text { plants }\end{array}$ & $\begin{array}{l}\text { Live } \\
\text { stocks }\end{array}$ & Orchards \\
\hline 1999 & 100 & 100 & 100 & 100 & 177713 & 84371 & 77426 & 15916 \\
\hline 2004 & 110.2 & 101.1 & 115.7 & 131.8 & 195861 & 85301 & 89587 & 20973 \\
\hline
\end{tabular}

\begin{tabular}{|l|l|l|l|}
\hline \multicolumn{4}{|c|}{ Agricultural production in \%. } \\
\hline Total & Agricultural plants & Livestock & Orchards \\
\hline 100 & 47.5 & 43.6 & 8.9 \\
\hline 100 & 43.6 & 45.7 & 10.7 \\
\hline
\end{tabular}

\begin{tabular}{|c|c|c|c|c|c|c|}
\hline \multicolumn{6}{|c|}{ Value of agricultural production in $000 /$ lekë. } & \multirow{3}{*}{\begin{tabular}{|c|}
$\begin{array}{c}000 \\
\text { lekë/100 ha }\end{array}$ \\
Total \\
328437 \\
\end{tabular}} \\
\hline \multicolumn{2}{|c|}{ Description } & Total & Agricultural & Live stock & Orchards & \\
\hline \multirow{2}{*}{ 漓 } & 1998 & 5802505 & 3336343 & 2082026 & 384136 & \\
\hline & 1999 & 3904184.3 & 3032069 & 277757.3 & 594358 & 22098.7 \\
\hline \multirow[b]{2}{*}{ 吾 } & 1994 & 1193280 & 537060 & 426270 & 229950 & 8241.2 \\
\hline & 1999 & 2376935 & 1297278 & 978363 & 101294 & 16415.9 \\
\hline \multirow{3}{*}{ } & 1994 & 1200303.4 & 433135.9 & 733969.5 & 33198 & 9194.2 \\
\hline & 1998 & 2631431 & 998555 & 1569289 & 63587 & 20156.5 \\
\hline & 1999 & 3024396 & 1115674 & 1828410 & 80312 & 23166.6 \\
\hline
\end{tabular}

Livestock production is increased with a quick pace and have taken the first place for the in the general agricultural production, postponing in the second place production of 
plants. Livestock development was high and required more food, so it was necessary the increase of planted surfaces with corns and fodders.

Table 9. Structure of incomes of agricultural production according to branches in \%

\begin{tabular}{|c|c|c|c|c|}
\hline \multicolumn{2}{|c|}{ Branches } & Agriculture & Livestock & Orchards \\
\hline \multicolumn{2}{|c|}{ Region 2005} & 46 & 48 & 6 \\
\hline \multirow{2}{*}{$\stackrel{\dot{\Xi}}{\vdots}$} & 1998 & 57.5 & 35.9 & 6.6 \\
\hline & 1999 & 47.3 & 43.4 & 9.3 \\
\hline \multirow{3}{*}{ : } & 1994 & 45 & 35.7 & 19.3 \\
\hline & 1998 & 49.8 & 45.7 & 4.5 \\
\hline & 1999 & 54.5 & 41.2 & 4.3 \\
\hline \multirow{3}{*}{ 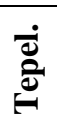 } & 1994 & 36.1 & 61.1 & 2.8 \\
\hline & 1998 & 38 & 59.6 & 2.4 \\
\hline & 1999 & 36.9 & 60.4 & 2.7 \\
\hline
\end{tabular}

Units of agricultural products (farms) are very small and surfaces they possess are segmented and this makes difficult, the normal development of productive activities.

Figure 3. Dynamic of agricultural productions in \% Republic of Albania

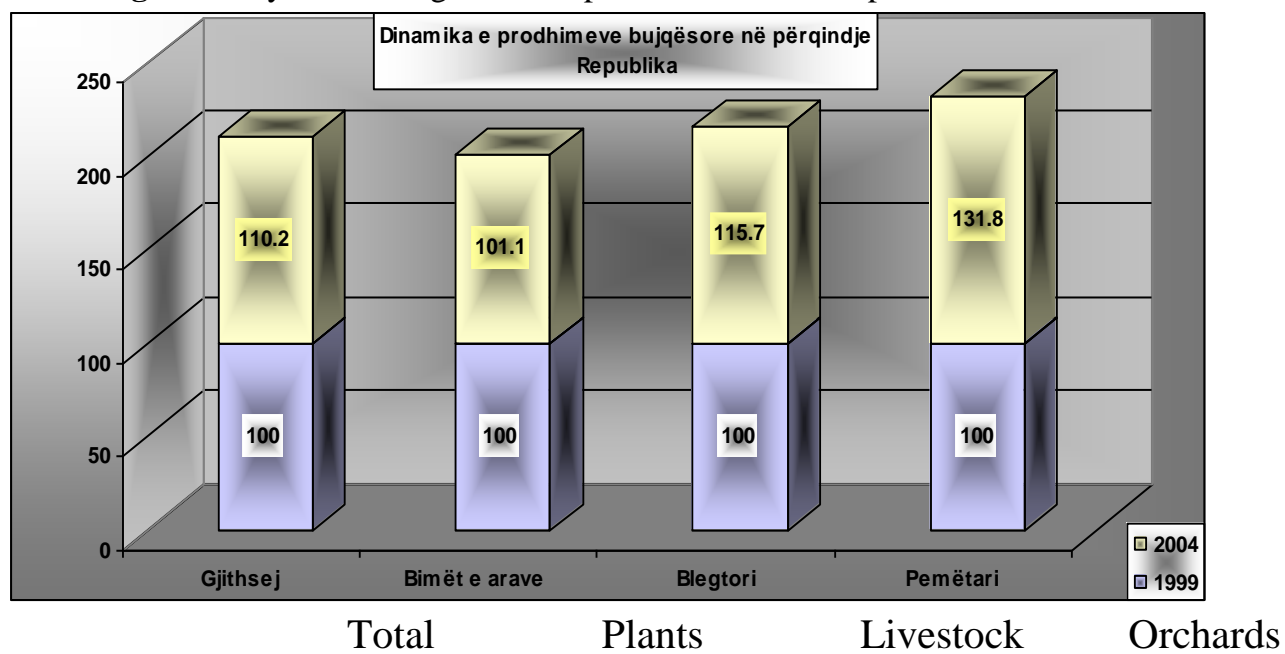

Marketing systems and processing of agricultural and livestock products are not enough functional. Profitability of agricultural production units is very low.

Figure 4. Agricultural production in \%

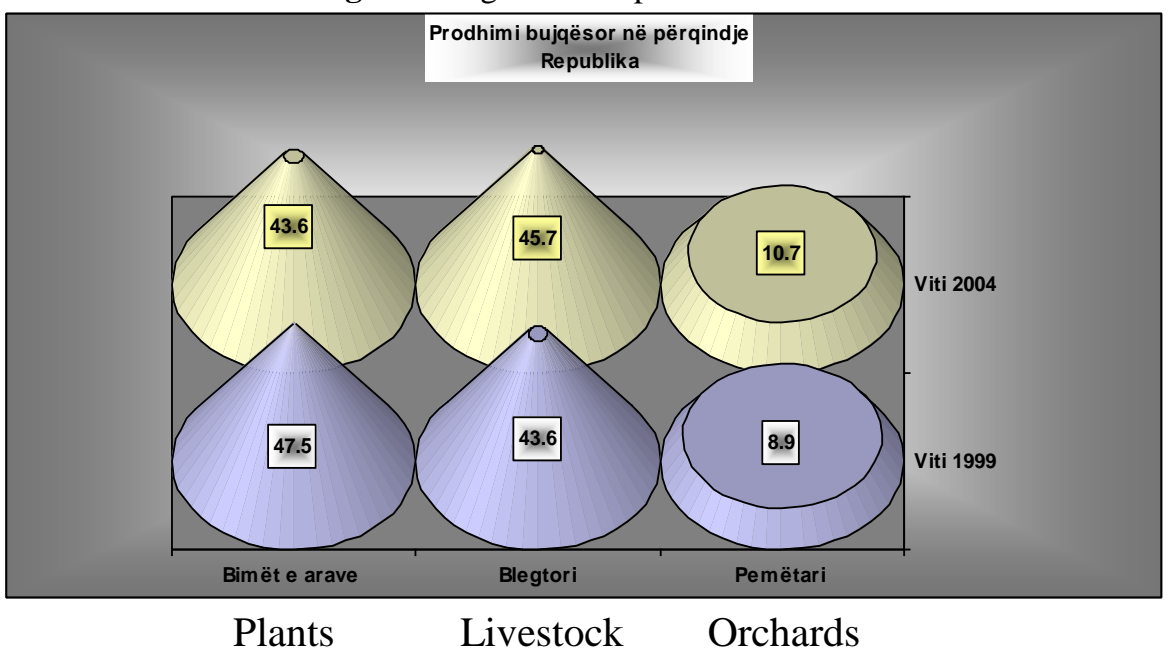


Figure 5. Structure of incomes of agricultural products according to the branches in \%

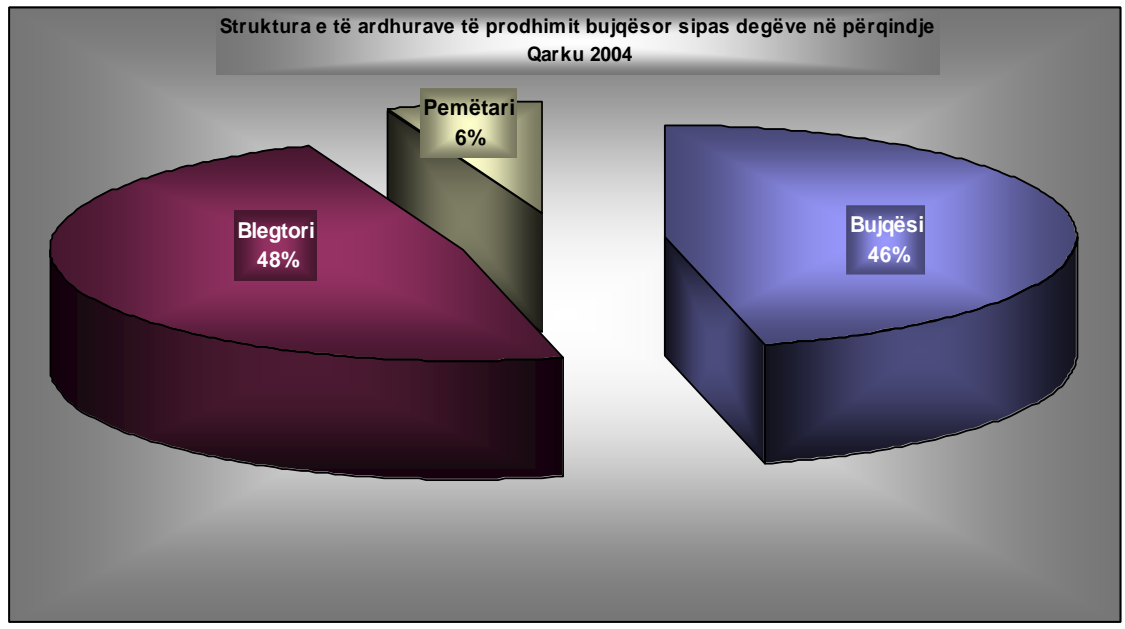

Figure 6. Structure of incomes of agricultural products in Gjirokastra District

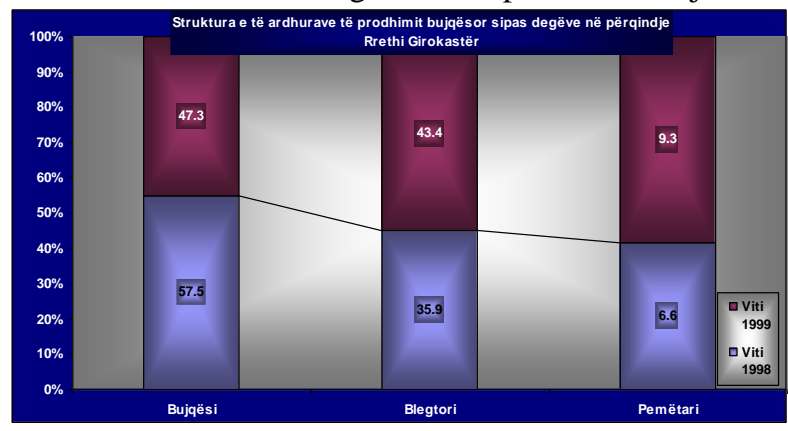

Figure 7. Structure of incomes of agricultural products in Permeti District

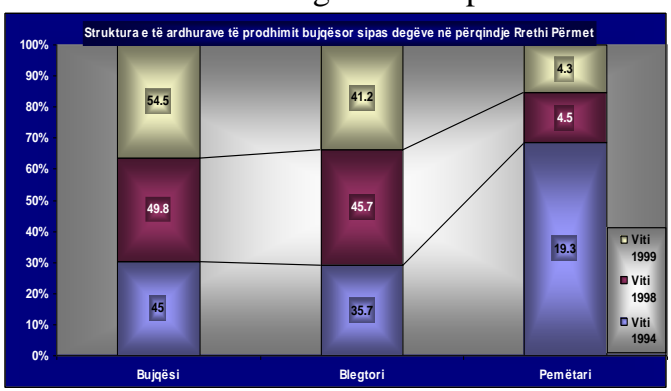

Figure 8. Structure of incomes of agricultural products in Tepelena District

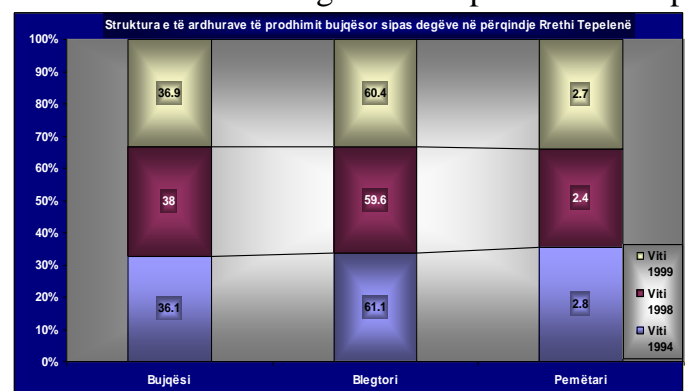

Agriculture Livestock Orchards 
Consequences of agricultural reform:

-Were substituted big units of agricultural products with small familiar units that possessed averagely 1.26 ha/family ( $1.17 \mathrm{ha} /$ family in the whole country),divided in 3-4 plots;

- Process was accompanied with a chaotic urbanization, big segmentation and misuse of agricultural lands;

- Agricultural infrastructure, watering and draining system and trading of agricultural products was very damaged;

- Law Nr. 7501 didn't take in consideration the ownership of the land before the Agricultural Reform in1945-1946, so agricultural land wasn't returned to the former owners of before collectivization phase, but it was delivered to the families that were living in the village till 31 July 1991;

- Employment level in rural areas was increased;

-Were created premises for interior migrations (toward flat areas and urban centres creating informal inhabitation areas) and emigration of rural population outside the country (mainly in Greece and Italy);

- Remittances of money from outside favour laziness and parasitism of rural population, abandoning the land decreasing the agricultural production.

In such conditions it was necessary:

- To complete land registration and reownership of former owners, that will bring revitalizacion of agricultural economy and increase of investments;

- Good administration of agricultural land;

- Rehabilitation of watering and draining system, especially of irrigation channels of second and third hand owned by the farmers, since the damage of damns and embankments caused over flooding of agricultural areas in communes of Luftinjë, Krahës, Buz, Qesarat, Sukë, Dëshnicë, Ballaban etj. Also use of inerts from the river banks, parts of embankments and their use without any criteria have increased the damages caused from over flooding of agricultural lands;

- It is created a private sector of seeds production, agricultural mechanicals, inputs and agro chemicals;

- To protect the land from erosions and to increase it fertility;

- To do re dimensioning of plots to make them rentable and suitable for the application of modern technologies;

- To improve lands through planting of improved products (crops, fodders grown in hilly areas (5-25\%) and mountainous areas (over 25\%);

- Improving production of plants livestock, agro food products and fishing;

- To protect agricultural land from illegal constructions, which were decreasing its stock;

- To create and develop functional market of the land;

- Organizing of financial service system in rural areas;

- To solve furnishing with inputs and transferring of technologies;

- Reorganizing and modernizing local and regional agricultural markets;

- To improve and modernise information and technical assistance in agriculture.

Conclusion: Implementation of "Law 7501 about Land" has changed ownership rapports in the villages, but didn't solve conflicts that have to do with ownership of agricultural land. Possibilities created by economy of free market should affect the development of rural economy, but the state should negotiate re dimensioning of properties, crediting the production, creation of processing and trading infrastructure, modernizing of agricultural sector etc, in order to increase interest of farmers in this sector. 


\section{REFERENCES}

1. Banka Botërore. (2002) Strategjia e zhvillimit rural për Shqipërinë, Tiranë.

2. Fishta, I., Toçi V. (1981) Reforma Agrare - revolucioni $i$ parë në marrëdhëniet ekonomiko-shoqërore në fshatin shqiptar. (1944 - 1946), Studime Historike 1, Viti XXXV (XVIII), Tiranë.

3. Fishta, I., Ziu M. (2004) Historia e ekonomisë së Shqipërisë (1944 - 1960) "Dita", Tiranë.

4. Gillardot P. (1997) Géographie rurale, Imprimeur, Paris.

5. Gjata, M., Damo, R. (1999) Bujqësia e qëndrueshme në dhjetëvjeçarin e ardhshëm, Bujqësia Shqiptare, Tiranë.

6. Karthala. (2000) Agricultures familiales et développement rural en Méditerranée, RAFAC, France.

7. Kovaçi, K. (1996) Fermat familjare në Shqipëri. Perspektiva e zhvillimit të tyre, Ekonomia dhe tranzicioni $1-4$, Tiranë.

8. Laçi, S. (1997) Aspekte të zbatimit të ligjit për Tokën, Studime Albanologjike I, 1997/1 Viti II (3 ), Tiranë.

9. Laçi, S. (1998) Bujqësia shqiptare në tranzicion. Aspekte të evolucionit gjatë periudhës 1991-1997, Tiranë.

10. Smirnova, N. (2004) Historia e Shqipërisë përgjatë shekullit XX , "Ideart", Tiranë.

11.Strategjia kombëtare e zhvillimit ekonomik dhe social, Tiranë 2004.

12.Zyra e administrimit dhe mbrojtjes së tokës pranë këshillit të qarkut Gjirokastër.

13.Zyra e kadastrës pranë këshillit të qarkut Gjirokastër. 